\title{
Dental students' perceptions of undergraduate Oral and Maxillofacial Surgery teaching in an integrated curriculum at Kuwait University
}

Mohammad Kamal ( $\square$ mkamal@hsc.edu.kw)

Kuwait University Faculty of Dentistry https://orcid.org/0000-0002-2833-4550

Mohammad Abdulwahab

Kuwait University Faculty of Dentistry

\section{Research article}

Keywords: dental students' perception, self-confidence, anatomical knowledge, oral surgery education, oral and maxillofacial surgery teaching

Posted Date: December 6th, 2020

DOl: https://doi.org/10.21203/rs.3.rs-31025/v2

License: (c) (1) This work is licensed under a Creative Commons Attribution 4.0 International License.

Read Full License

Version of Record: A version of this preprint was published at BMC Medical Education on April 7th, 2021. See the published version at https://doi.org/10.1186/s12909-021-02614-x. 


\section{Abstract}

Background: To evaluate dental students' perceptions of the undergraduate oral and maxillofacial surgical training teaching curriculum according to a validated questionnaire originally developed by the Association of British Academic Oral Maxillofacial Surgeons (ABAOMS) to assess their self-confidence.

Methods: A cross-sectional survey of all 6th-year $(n=22)$ and 7th-year $(n=21)$ dentistry students that was conducted Kuwait University Faculty of Dentistry between 1 and 15 May 2020. A previously implemented and validated questionnaire by ABAOMS was used in the study, which is made of 17 questions assessing various areas of the undergraduate OMFS curriculum in the clinical years. The response options to the questionnaire questions were on a Likert scale. Independent sample t-tests were performed to assess the difference in responses between the two groups. Spearman's Rho correlations were calculated to measure the strength of association between confidence in all aspects of surgical and forceps exodontia. Statistical significance was considered to be a p-value $<0.05$.

Results: A total of 39 questionnaires were completed by the students. The majority of students expressed that they feel confident that they have enough knowledge to undertake independent practice $(61 \%)$. General aspects of the questionnaire were answered favourably except for the step of surgical extraction of teeth, in which both classes reported a lower level of confidence.

Conclusions: This survey revealed the students' self-confidence undertaking independent practice and preforming basic oral surgery procedures. Students felt comfortable with exodontia using forceps and elevators, root removal, managing acute pericoronitis, managing haemorrhage from a socket, assessing impacted teeth, and recognising the clinical features of potentially malignant and malignant lesions of the oral cavity. They reported a lower level of confidence for performing the steps of surgical procedures. The ABAOMS survey instrument is a useful and thorough tool to assess the self-confidence of dental students according to their undergraduate oral and maxillofacial surgery teaching.

\section{Background}

A dental school teaching curriculum aims at providing the students with the highest theoretical and practical clinical education to prepare them for clinical practice. Several educational schemes and curricula have been developed across academic institutions internationally to enhance undergraduate education in the field of Oral and Maxillofacial Surgery. [1-3] Step-wise approach to teach practical procedures and thorough clinical assessments have allowed instructors to assess the educational level of the students and prepare them for the challenge to be faced in surgical education. [1, 3-5] To enhance the teaching experience, constant refinement of the OMFS teaching curriculum and clinical competency assessments, survey instruments have been developed to evaluate the self-confidence as perceived by undergraduate dental students in their clinical years with regard to performing the thought surgical procedures. Moreover, these survey instruments are also essentials to enhance educational quality and teaching effectiveness based on the student's feedback. $[3,4,6,7]$ The Association of British Academic 
Oral Maxillofacial Surgeons (ABAOMS) educational committee have constructed a thorough and validated questionnaire instrument to assess the self-confidence of the dental students according to their undergraduate oral and maxillofacial surgery teaching and have been used in several countries. [7-10] The ABAOMS instrument is made of 17 questions assessing the student's confidence in performing oral surgery procedures, the role of outreach in oral surgery, anatomy teaching in relation to oral surgery, and oral surgery career aspiration. [7]

The Faculty of Dentistry at Kuwait University started the undergraduate Oral and Maxillofacial Surgery teaching curriculum in 2002 when the dental students started their clinical years. Kuwait University follows a 7-year dentistry program, in which the students start their clinical training in the $5^{\text {th }}$ year of the program, which courses focusing on Oral and Maxillofacial Surgery being introduced from the $5^{\text {th }}$ to the $7^{\text {th }}$ year of their dental studies. Students' perceptions of their oral and maxillofacial surgery training have received little attention, and there have been no prior studies assessing the students' views on their oral surgery educations and their level of confidence to conduct surgical procedures. Our aim is to evaluate the dental students' perceptions the undergraduate oral and maxillofacial surgical training teaching curriculum according to a validated questionnaire originally developed by the Association of British Academic Oral Maxillofacial Surgeons (ABAOMS) to assess their self-confidence and readiness to perform common oral surgical procedures.

\section{Methods}

This is a cross-sectional survey of all 6th-year ( $\mathrm{n}=22$ students) and 7th-year ( $\mathrm{n}=21$ students) dentistry students that were Kuwait University Faculty of Dentistry between May $1^{\text {st }}$ to $15^{\text {th }} 2020$. Students were consented to voluntarily fill out the survey instruments, and of the responses remained anonymous throughout the study. The study protocol was approved by the Ethical Committee at Kuwait University Health Sciences Center, according to the Helsinki Declaration. A previously introduced and validated questionnaire by Association of British Academic Oral Maxillofacial Surgeons (ABAOMS) was used to conduct the study. $[7,10]$ The survey was distributed electronically using Google Forms (https://www.google.com/forms) to all students at Kuwait Universal via student portal network. Students were asked to provide information about age, class, gender and number of extractions performed, along with 17 questions assessing various areas of the undergraduate OMFS curriculum in the clinical years. The response options to the questionnaire questions were on a Likert-type scale, with 5 items ranging from strongly agree, to strongly disagree.

The data was analysed using SPSS version 23 (SPSS; IBM Company, Chicago, IL, USA). Responses to the questionnaire were analysed according to the year the dentistry student was in (6th or 7th year) and summarised as counts and percentages. Independent sample t-tests were also performed to assess the difference in responses between the two groups. Spearman's Rho correlations were calculated to measure the strength of association between confidence in all aspects of surgical and forceps exodontia. Additional analysis was performed to measure the Spearman's rho correlations between confidence in 
surgical and forceps exodontia and anatomical teaching. Statistical significance was considered to be a p-value $<0.05$.

\section{Results}

A total of 39 questionnaires were completed by the students, with a response rate of $90,90 \%$ for the sixthyear students ( $n=20$ of 22), and $90,47 \%$ of the seventh-year students ( $n=19$ of 21 ), Table 1 . Thirty-seven respondents were female (94.9\%) reflecting the majority of female students at the faculty. The Likert response to each statement in the questionnaire regarding confidence in oral surgery procedures, dental anatomy and enjoyment of oral surgery, by year, is shown in Table 2 .

The majority of students expressed that they feel confident that they have enough knowledge to undertake independent practice (61\%). However, the difference between the $7^{\text {th }}$ year students compared to $6^{\text {th }}$ year students $(78.9 \%$ vs $45 \%$, p-value $=0.051)$ was not statistically significant. Both $7^{\text {th }}$ and $6^{\text {th }}$-year students felt confident that they could extract an upper single-rooted tooth with an intact crown $(94.7 \%$ and $90 \%$ respectively). Both groups were also confident that they could remove visible retained roots of an upper left first molar with elevators or forceps ( $84.2 \%$ and $65 \%$ respectively). The majority of students (74.4\%) expressed that they viewed oral surgery as an enjoyable and rewarding discipline. The majority of students had some experience at an off-campus dentistry centre (59\%). However, less than half (41\%) carried out simple extractions at this off-campus site, and only 2 students $(5.1 \%)$ performed a surgical extraction off-campus (Table 3). In terms of the number of teeth extracted, the median number of teeth extracted by the 7 th year students was $>25$ teeth, while the median for the 6 th year students was 20-25 teeth (Table 1).

Significant positive correlations were found between confidence in almost all aspects of surgical and forceps exodontia (Table 4). Only the correlation between confidence in extracting a single tooth and confidence in managing a failed extraction necessitating bone removal did not reach statistical significance ( $p$-value $=0.075$ ). The belief that anatomy teaching was appropriate (D1) correlated well with confidence in most aspects of surgical and forceps exodontia (Table 5). When questioned about confidence in undertaking oral surgery because of their knowledge and understanding of anatomy (D3), the only significant correlation was with confidence in managing a failed extraction necessitating the raising of a mucoperiosteal flap (B4a).

\section{Discussion}

In recent years, there has been an increase in the number of dental schools around the world with heterogenous standards of their undergraduate teaching curriculum, years of training, and numbers of qualified teaching faculty members. $[4,7,8]$ As a result, this makes it difficult to have a recognised standardisation across dental schools. A study by Lee et al. demonstrated that the dental students' undergraduate grades and their scores on the standardised dental admission test were poor predictors of performance on assessment examination that are used for residency admission in Oral and Maxillofacial 
Surgery. [11] A major part of any dental school curriculum relies on helping the students acquire predefined clinical competencies and technical skills, and many consider the mastery of these technical skills to be of the highest importance in clinical practice. [3,6] Thus, one of the major objectives of any dental school curriculum lies in attaining clinical competency and the required self-confidence by the students. [3] Student self-assessment of their own knowledge and level of confidence and knowledge to complete clinical technical skills has been previously used in the field of dentistry and oral surgery. [1-4, 7$10,12-15]$

Given that the department of Oral and Maxillofacial Surgery at Kuwait University is a fairly young one, and has commenced its teaching activities in 2002, such a feedback from the students is of paramount importance to us to refine our teaching goals and competencies. The response rate seen in the studies reflects the interest of the students to voluntarily assess their undergraduate OMFS teaching in preparation for their entry in the dentistry practice. Table 1 . The majority of the dental students were females, which indicates the overall interest of the female students in Kuwait to embark on a career in the field of dentistry. Even though the class sizes are small, the responses of the students were regarded as promising as they feel confident that they have enough knowledge to undertake independent practice (61\%). Overall, when assessing their readiness to undertake private practice and perform extractions with forceps and minor oral surgery procedures, the scores were favourable and being in line with previous studies utilising the same survey instrument. [3, 4, 7-10]

When assessing their technical skills to extract an upper single-rooted tooth with an intact crown, both the $7^{\text {th }}$ and $6^{\text {th }}$-year students felt confident that they could ( $94.7 \%$ and $90 \%$ respectively). In addition, both groups were also confident that they could remove visible retained roots of an upper left first molar with elevators or forceps ( $84.2 \%$ and $65 \%$ respectively). This finding was different from a previous study by Burdurlu et al., in which the upper class reported being more confident than their counterparts in the year younger. [8] This could be due to the fact that dental students at Kuwait University undergo a more extensive teaching curriculum due to a longer study period, where dentistry studies take seven years, with the last 2 and $1 / 2$ years being considered as clinical years, whereas in the study by Burdurlu et al., the study program was of five-year duration. Nevertheless, the responses between the $7^{\text {th }}$ year and $6^{\text {th }}$ year students were statistically different when reporting their level of confidence for performing surgical procedures, ranging from raising of a mucoperiosteal flap, to sectioning of teeth, to bone removal, to wound closure and suturing, Table2. This, however, was in line with other studies which reported relatively less selfconfidence in conducting surgical extractions $[4,8,9,14]$. Responses about the level of confidence in diagnosing and managing acute pericoronitis, assessing impacted third molars, or managing haemorrhage from a socket were more favourable than recognising benign and malignant conditions, or differentiating pain origins, or writing detailed referral letters to other specialists, Table 2. This was also following the same pattern in the previous studies by Cabbar, Burdurlu, and Macluskey. [7-10] One explanation to why most students score relatively low in their confidence to conduct surgical extraction is that it is considered the most invasive procedure across the whole spectrum of dental procedure which 
the students get exposed to during their dental school training, and even if they are clinically competent as dentists, they feel intimidated by it. $[9,16]$

When assessing anatomical knowledge, the responses from the students indicate that their teaching was sufficient to prepare them to face oral surgical clinical scenarios, and the response was not statistically significant between sixth- and seventh-year students. This maybe is because the students receive extensive didactic OMFS teaching in their clinical years with a strong emphasis on clinical head and neck anatomy. The importance of instilling constant anatomical knowledge during dental education to help with the consolidation and retention of the clinical grasp was previously advocated by Thomas et al. [8, 17] The fact that both classes disagreed unequivocally to the item that only anatomical knowledge needed for oral surgery is that of jaw and tooth morphology shows a maturation of their understanding that general anatomy knowledge is of paramount importance when treating patients or performing oral surgical procedures. The role off-campus learning needs to emphasised in our teaching, to increase the exposure of the students to the more complex procedures that are not heavily emphasised in the dental school's clinic.

In our study we found that students in both junior and senior clinical years have sufficient level of confidence to perform extractions by the use of forceps, and a good higher level of confidence when diagnosing conditions commonly seen in oral surgery practice, such as management acute pericoronitis, manage haemorrhage from a socket, assessing impacted teeth, and recognising the clinical features of potentially malignant and malignant lesions of the oral cavity. However, both classes showed a lower level of self-confidence in performing more invasive procedures such as raising of a flap, sectioning of teeth and bone removal, and wound close with suturing. This prompts us to put more emphasis on our hands-on training sessions, utilising phantom heads in oral surgical education, assisting in the major surgical procedures, and utilising novel models to conduct these surgical procedures which are considered to be essential for dentists wanting to practice the whole spectrum of general dentistry in clinical practice.

\section{Conclusions}

Students felt confident undertaking independent practice and preforming exodontia using forceps and elevators, root removal, managing acute pericoronitis, managing haemorrhage from a socket, assessing impacted teeth, and recognising the clinical features of potentially malignant and malignant lesions of the oral cavity. They reported a lower level of confidence for performing surgical procedures, ranging from raising of a mucoperiosteal flap, to sectioning of teeth, to bone removal, to wound closure and suturing, and writing of a detailed referral letter to specialists. This should prompt us to increase their clinical exposure to these procedures in the faculty clinic and off-campus rotations, and refine our training schemes in the areas of surgical extractions and procedures related to minor oral surgery, such as raising a flap, bone removal, root section, and wound suturing. The ABAOMS survey instrument is a useful and thorough tool to assess the self-confidence of dental students according to their undergraduate oral and maxillofacial surgery teaching. 


\section{Declarations}

\section{Ethics approval and consent to participate:}

Participating students gave consent and voluntarily filled out the questionnaire, and their responses were kept anonymous. The Ethical Committee at Kuwait University approved the study, in accordance with the Helsinki Declaration.

\section{Consent for publication:}

Not applicable.

\section{Availability of data and materials:}

The data used in this study are not publicly available for privacy reasons, but data can be made available from the corresponding author on request.

\section{Competing interests:}

The authors declare that they have no competing interests.

\section{Funding:}

None.

\section{Authors' contributions:}

MK and MA conceived and designed the study. MK collected the data work on the acquisition and analyses. MK interpret the data. MK and MA have drafted the work or substantively revised it. All authors read and approved the final manuscript.

\section{Acknowledgements:}

None.

\section{References}

1. Macluskey M, Durham J: Oral surgery undergraduate teaching and experience in the United Kingdom: a national survey. European Journal of Dental Education 2009, 13(1):52-57.

2. Macluskey M, Durham J, Cowan G, Cowpe J, Evans A, Freeman C, Jephcott A, Jones J, Millsopp L, Oliver R: UK national curriculum for undergraduate oral surgery subgroup for teaching of the Association of British Academic Oral and Maxillofacial Surgeons. European Journal of Dental Education 2008, 12(1):48-58. 
3. Wanigasooriya N: Student self-assessment of essential skills in dental surgery. British Dental Journal 2004, 197(5):11-14.

4. Al-Dajani M: Dental students' perceptions of undergraduate clinical training in oral and maxillofacial surgery in an integrated curriculum in Saudi Arabia. Journal of Educational Evaluation for Health Professions 2015, 12.

5. Macluskey M, Hanson C, Kershaw A, Wight A, Ogden G: Development of a structured clinical operative test (SCOT) in the assessment of practical ability in the oral surgery undergraduate curriculum. British Dental Journal 2004, 196(4):225.

6. Buck D, Malik S, Murphy N, Patel V, Singh S, Syed B, Vorah N: What makes a good dentist and do recent trainees make the grade? The views of vocational trainers. British Dental Journal 2000, 189(10):563-566.

7. Macluskey M, Durham J, Bell A, Cowpe J, Crean SJ, Dargue A, Dawson L, Freeman C, Jones J, McDouagh A: A national survey of UK final year students' opinion of undergraduate oral surgery teaching. European Journal of Dental Education 2012, 16(1):e205-e212.

8. Burdurlu MÇ, Cabbar F, Dagasan V, Çukurova ZG, Doğanay Ö, Ülker GMY, Atalay B, Gönül O, Tomruk CO: A city-wide survey of dental students' opinions on undergraduate oral surgery teaching. European Journal of Dental Education 2020.

9. Cabbar F, Burdurlu MÇ, Tomruk CO, Bank B, Atalay B: Students' perspectives on undergraduate oral surgery education. BMC Medical Education 2019, 19(1):265.

10. Macluskey M, Shepherd S, Carter E, Bulsara Y, Durham J, Bell A, Dargue A, Emanuel C, Freeman C, Jones J: A national follow-up survey of UK graduates opinion of undergraduate oral surgery teaching. European Journal of Dental Education 2016, 20(3):174-179.

11. Lee KC, Lee VY, Zubiaurre LA, Grbic JT, Eisig SB: Relationship Between Dental Students' PreAdmission Record and Performance on the Comprehensive Basic Science Examination. Journal of Dental Education 2018, 82(4):424-428.

12. Brand H, Tan L, van der Spek S, Baart J: European dental students' opinions on their local anaesthesia education. European Journal of Dental Education 2011, 15(1):47-52.

13. Henzi D, Davis E, Jasinevicius R, Hendricson W: North American dental students' perspectives about their clinical education. Journal of Dental Education 2006, 70(4):361-377.

14. Henzi D, Davis E, Jasinevicius R, Hendricson W: In the students' own words: what are the strengths and weaknesses of the dental school curriculum? Journal of Dental Education 2007, 71(5):632-645.

15. Shah S, Halai T, Patel J, Sproat C: Perceived confidence and experience in oral surgery among final year undergraduate students in a UK dental school. British Dental Journal 2018, 224(3):177.

16. Durham J, Moore U, Corbett I, Thomson P: Assessing competency in dentoalveolar surgery: a 3-year study of cumulative experience in the undergraduate curriculum. European Journal of Dental Education 2007, 11(4):200-207.

17. Thomas SJ, Atkinson C, Hughes C, Revington P, Ness AR: Is there an epidemic of admissions for surgical treatment of dental abscesses in the UK? BMJ 2008, 336(7655):1219-1220. 


\section{Tables}

Table 1. Students characteristics and number of extractions performed.

\begin{tabular}{|c|c|c|c|c|c|c|c|c|c|}
\hline Group & Respondents & Response & Age & Gender & \multicolumn{5}{|c|}{ Number of extractions performed - \% } \\
\hline Class & $\mathrm{n}$ & $\%$ & Mean & Male/Female & $<10$ & $10-15$ & $15-20$ & $20-25$ & $>25$ \\
\hline $\begin{array}{l}6 \text { th } \\
\text { year }\end{array}$ & 20 of 22 & $90.90 \%$ & 23.25 & $\begin{array}{c}1 \text { Male } \\
29 \text { Female } \\
\end{array}$ & $\begin{array}{c}3 \\
(15 \%) \\
\end{array}$ & $\begin{array}{c}2 \\
(10 \%) \\
\end{array}$ & $4(20 \%)$ & $4(20 \%)$ & $7(35 \%)$ \\
\hline $\begin{array}{l}7 \text { th } \\
\text { year }\end{array}$ & 19 of 21 & $90.47 \%$ & 24.26 & $\begin{array}{c}2 \text { Male } \\
17 \text { Female }\end{array}$ & 0 & $\begin{array}{c}1 \\
(5.3 \%) \\
\end{array}$ & 0 & $\begin{array}{c}3 \\
(15.8 \%)\end{array}$ & $\begin{array}{c}15 \\
(78.9 \%) \\
\end{array}$ \\
\hline Total & 39 of 43 & $90.79 \%$ & 23.76 & 23,76 & $\begin{array}{c}3 \\
(7.7 \%) \\
\end{array}$ & $\begin{array}{c}3 \\
(7.7 \%) \\
\end{array}$ & $\begin{array}{c}4 \\
(10.3 \%) \\
\end{array}$ & $\begin{array}{c}7 \\
(17.9 \%) \\
\end{array}$ & $\begin{array}{c}22 \\
(56.4 \%) \\
\end{array}$ \\
\hline
\end{tabular}

Table 2. The frequency of answers for each of the questions; \% response by likert scale (Independent t-test) 


\begin{tabular}{|c|c|c|c|c|c|c|c|c|}
\hline Question/Statement & Class & $\begin{array}{c}\text { Strongly } \\
\text { agree }\end{array}$ & Agree & Unsure & Disagree & $\begin{array}{l}\text { Strongly } \\
\text { Disagree }\end{array}$ & $\begin{array}{l}\text { Mean } \\
\pm \text { STD } \\
\end{array}$ & $\begin{array}{c}\mathrm{p}- \\
\text { value }\end{array}$ \\
\hline \multirow{2}{*}{$\begin{array}{l}\text { B1. The teaching that I have } \\
\text { received in oral surgery has } \\
\text { given me sufficient } \\
\text { knowledge to undertake } \\
\text { independent practice }\end{array}$} & $\begin{array}{c}6^{\text {th }} \\
\text { year }\end{array}$ & $2(10 \%)$ & $7(35 \%)$ & $7(35 \%)$ & $4(20 \%)$ & 0 & $\begin{array}{c}2.65 \\
( \pm 0.93)\end{array}$ & 0.051 \\
\hline & $\begin{array}{c}7^{\text {th }} \\
\text { year }\end{array}$ & $\begin{array}{c}5 \\
(26.3 \%) \\
\end{array}$ & $\begin{array}{c}10 \\
(52.6 \%) \\
\end{array}$ & $\begin{array}{c}2 \\
(10.5 \%) \\
\end{array}$ & $\begin{array}{c}2 \\
(10.5 \%) \\
\end{array}$ & 0 & $\begin{array}{c}2.05 \\
( \pm 0.91) \\
\end{array}$ & \\
\hline \multirow{2}{*}{$\begin{array}{l}\text { B2. I feel confident that I } \\
\text { could extract an upper } \\
\text { single- rooted tooth with an } \\
\text { intact crown, in an } \\
\text { otherwise intact dentition }\end{array}$} & $\begin{array}{c}6^{\text {th }} \\
\text { year }\end{array}$ & $\begin{array}{c}11 \\
(55 \%)\end{array}$ & $9(45 \%)$ & 0 & 0 & 0 & $\begin{array}{c}1.45 \\
( \pm 0.51)\end{array}$ & 0.161 \\
\hline & $\begin{array}{c}7^{\text {th }} \\
\text { year }\end{array}$ & $\begin{array}{c}16 \\
(84.2 \%) \\
\end{array}$ & $\begin{array}{c}2 \\
(10.5 \%) \\
\end{array}$ & $\begin{array}{c}1 \\
(5.3 \%) \\
\end{array}$ & 0 & 0 & $\begin{array}{c}1.21 \\
( \pm 0.54) \\
\end{array}$ & \\
\hline \multirow{2}{*}{$\begin{array}{l}\text { B3. I feel confident that I } \\
\text { could remove visible } \\
\text { retained roots of an upper } \\
\text { left first molar with } \\
\text { elevators or forceps }\end{array}$} & $\begin{array}{c}6^{\text {th }} \\
\text { year }\end{array}$ & $6(30 \%)$ & $7(35 \%)$ & $3(15 \%)$ & $4(20 \%)$ & 0 & $\begin{array}{c}2.25 \\
( \pm 1.1)\end{array}$ & 0.157 \\
\hline & $\begin{array}{c}7^{\text {th }} \\
\text { year }\end{array}$ & $\begin{array}{c}11 \\
(57.9 \%)\end{array}$ & $\begin{array}{c}5 \\
(26.3 \%)\end{array}$ & 0 & $\begin{array}{c}3 \\
(15.8 \%)\end{array}$ & 0 & $\begin{array}{c}1.74 \\
( \pm 1.10)\end{array}$ & \\
\hline \multicolumn{9}{|l|}{$\begin{array}{l}\text { B4. I feel confident to } \\
\text { assess and perform the } \\
\text { surgical management of a } \\
\text { failed extraction (e.g. a } \\
\text { lower second molar) } \\
\text { necessitating: }\end{array}$} \\
\hline \multirow[t]{2}{*}{$\begin{array}{l}\text { B4a. The raising of a } \\
\text { mucoperiosteal flap }\end{array}$} & $\begin{array}{c}6^{\text {th }} \\
\text { year }\end{array}$ & 0 & $2(10 \%)$ & 0 & $9(45 \%)$ & $9(45 \%)$ & $\begin{array}{c}4.25 \\
( \pm 0.91) \\
\end{array}$ & $<0.001$ \\
\hline & $\begin{array}{c}7^{\text {th }} \\
\text { year }\end{array}$ & 0 & $\begin{array}{c}6 \\
(31.6 \%) \\
\end{array}$ & $\begin{array}{c}8 \\
(42.1 \%) \\
\end{array}$ & $\begin{array}{c}3 \\
(15.8 \%) \\
\end{array}$ & $\begin{array}{c}2 \\
(10.5 \%) \\
\end{array}$ & $\begin{array}{c}3.05 \\
( \pm 0.97) \\
\end{array}$ & \\
\hline \multirow[t]{2}{*}{ B4b. Bone removal } & $\begin{array}{c}6^{\text {th }} \\
\text { year }\end{array}$ & 0 & $1(5 \%)$ & $5(25 \%)$ & $6(30 \%)$ & $8(40 \%)$ & $\begin{array}{c}4.05 \\
( \pm 0.94)\end{array}$ & 0.002 \\
\hline & $\begin{array}{c}7^{\text {th }} \\
\text { year }\end{array}$ & 0 & $\begin{array}{c}6 \\
(31.6 \%) \\
\end{array}$ & $\begin{array}{c}8 \\
(42.1 \%) \\
\end{array}$ & $\begin{array}{c}3 \\
(15.8 \%)\end{array}$ & $\begin{array}{c}2 \\
(10.5 \%)\end{array}$ & $\begin{array}{c}3.05 \\
(0.97) \\
\end{array}$ & \\
\hline \multirow{2}{*}{$\begin{array}{l}\text { B4c. Sectioning the tooth to } \\
\text { facilitate elevation of the } \\
\text { roots }\end{array}$} & $\begin{array}{c}6^{\text {th }} \\
\text { year }\end{array}$ & 0 & $1(5 \%)$ & 0 & $9(45 \%)$ & $\begin{array}{c}10 \\
(50 \%)\end{array}$ & $\begin{array}{c}4.40 \\
( \pm 0.75)\end{array}$ & $<0.001$ \\
\hline & $\begin{array}{c}7^{\text {th }} \\
\text { year }\end{array}$ & 0 & $\begin{array}{c}6 \\
(31.6 \%) \\
\end{array}$ & $\begin{array}{c}9 \\
(47.4 \%) \\
\end{array}$ & $\begin{array}{c}2 \\
(10.5 \%) \\
\end{array}$ & $\begin{array}{c}2 \\
(10.5 \%) \\
\end{array}$ & $\begin{array}{c}3.00 \\
(0.94) \\
\end{array}$ & \\
\hline \multirow{2}{*}{$\begin{array}{l}\text { B4d. Wound closure using } \\
\text { appropriate suture } \\
\text { materials }\end{array}$} & $\begin{array}{c}6^{\text {th }} \\
\text { year }\end{array}$ & $2(10 \%)$ & $7(35 \%)$ & $4(20 \%)$ & $3(15 \%)$ & $4(20 \%)$ & $\begin{array}{c}3.00 \\
( \pm 1.34)\end{array}$ & 0.002 \\
\hline & $\begin{array}{c}7^{\text {th }} \\
\text { year }\end{array}$ & $\begin{array}{c}11 \\
(57.9 \%) \\
\end{array}$ & $\begin{array}{c}5 \\
(26.3 \%) \\
\end{array}$ & $\begin{array}{c}2 \\
(10.5 \%) \\
\end{array}$ & 0 & $1(5.3 \%)$ & $\begin{array}{c}1.68 \\
( \pm 1.06) \\
\end{array}$ & \\
\hline \multirow[t]{2}{*}{$\begin{array}{l}\text { B5. I feel confident to } \\
\text { diagnose and manage acute } \\
\text { pericoronitis }\end{array}$} & $\begin{array}{c}6^{\text {th }} \\
\text { year }\end{array}$ & $6(30 \%)$ & $\begin{array}{c}10 \\
(50 \%)\end{array}$ & $4(20 \%)$ & 0 & 0 & $\begin{array}{c}1.90 \\
( \pm 0.72)\end{array}$ & 0.082 \\
\hline & $\begin{array}{c}7^{\text {th }} \\
\text { year }\end{array}$ & $\begin{array}{c}13 \\
(68.4 \%)\end{array}$ & $\begin{array}{c}3 \\
(15.8 \%)\end{array}$ & $\begin{array}{c}3 \\
(15.8 \%)\end{array}$ & 0 & 0 & $\begin{array}{c}1.47 \\
( \pm 0.77)\end{array}$ & \\
\hline \multirow[t]{2}{*}{$\begin{array}{l}\text { B6. I feel confident to } \\
\text { manage haemorrhage from } \\
\text { a socket }\end{array}$} & $\begin{array}{c}6^{\text {th }} \\
\text { year }\end{array}$ & $5(25 \%)$ & $9(45 \%)$ & $6(30 \%)$ & 0 & 0 & $\begin{array}{c}2.05 \\
( \pm 0.76)\end{array}$ & 0.732 \\
\hline & $\begin{array}{c}7^{\text {th }} \\
\text { year }\end{array}$ & $\begin{array}{c}7 \\
(36.8 \%) \\
\end{array}$ & $\begin{array}{c}9 \\
(47.4 \%) \\
\end{array}$ & $\begin{array}{c}1 \\
(5.3 \%)\end{array}$ & $1(5.3 \%)$ & $1(5.3 \%)$ & $\begin{array}{c}1.95 \\
( \pm 1.08)\end{array}$ & \\
\hline B7. I feel confident to & $6^{\text {th }}$ & $5(25 \%)$ & 14 & 0 & $1(5 \%)$ & 0 & 1.85 & 0.015 \\
\hline
\end{tabular}




\begin{tabular}{|c|c|c|c|c|c|c|c|c|}
\hline $\begin{array}{l}\text { assess an impacted } \\
\text { mandibular third molar with } \\
\text { respect to guidelines and } \\
\text { recognise the need for } \\
\text { surgical removal }\end{array}$ & year & & $(70 \%)$ & & & & $( \pm 0.67)$ & \\
\hline & $\begin{array}{c}7^{\text {th }} \\
\text { year }\end{array}$ & $\begin{array}{c}12 \\
(63.2 \%) \\
\end{array}$ & $\begin{array}{c}7 \\
(36.8 \%) \\
\end{array}$ & 0 & 0 & 0 & $\begin{array}{c}1.37 \\
( \pm 0.50) \\
\end{array}$ & \\
\hline \multirow{2}{*}{$\begin{array}{l}\text { B8. I feel confident that I } \\
\text { can recognise the clinical } \\
\text { features of potentially } \\
\text { malignant and malignant } \\
\text { lesions of the oral cavity }\end{array}$} & $\begin{array}{c}6^{\text {th }} \\
\text { year }\end{array}$ & $1(5 \%)$ & $\begin{array}{c}11 \\
(55 \%)\end{array}$ & $6(30 \%)$ & $2(10 \%)$ & 0 & $\begin{array}{c}2.45 \\
( \pm 0.76)\end{array}$ & 0.340 \\
\hline & $\begin{array}{c}7^{\text {th }} \\
\text { year }\end{array}$ & $\begin{array}{c}1 \\
(5.3 \%)\end{array}$ & $\begin{array}{c}15 \\
(78.9 \%)\end{array}$ & $\begin{array}{c}2 \\
(10.5 \%)\end{array}$ & 0 & $1(5.3 \%)$ & $\begin{array}{c}2.21 \\
( \pm 0.79)\end{array}$ & \\
\hline \multirow{2}{*}{$\begin{array}{l}\text { B9. I feel confident that I } \\
\text { can write an appropriate } \\
\text { referral letter to a specialist } \\
\text { in an appropriate time } \\
\text { frame dependent on the } \\
\text { clinical problem }\end{array}$} & $\begin{array}{c}6^{\text {th }} \\
\text { year }\end{array}$ & 0 & $9(45 \%)$ & 7 (35\%) & $4(20 \%)$ & 0 & $\begin{array}{c}2.75 \\
( \pm 0.79)\end{array}$ & 0.086 \\
\hline & $\begin{array}{c}7^{\text {th }} \\
\text { year }\end{array}$ & $\begin{array}{c}3 \\
(15.8 \%) \\
\end{array}$ & $\begin{array}{c}10 \\
(52.6 \%) \\
\end{array}$ & $\begin{array}{c}5 \\
(26.3 \%) \\
\end{array}$ & 0 & $1(5.3 \%)$ & $\begin{array}{c}2.26 \\
( \pm 0.93) \\
\end{array}$ & \\
\hline \multirow{2}{*}{$\begin{array}{l}\text { B10. I feel competent to } \\
\text { differentiate between pain } \\
\text { of odontogenic and non- } \\
\text { odontogenic origin }\end{array}$} & $\begin{array}{c}6^{\text {th }} \\
\text { year }\end{array}$ & 1 (5\%) & $\begin{array}{c}14 \\
(70 \%)\end{array}$ & $5(25 \%)$ & 0 & 0 & $\begin{array}{c}2.20 \\
( \pm 0.52)\end{array}$ & 0.971 \\
\hline & $\begin{array}{c}7^{\text {th }} \\
\text { year }\end{array}$ & $\begin{array}{c}7 \\
(36.8 \%) \\
\end{array}$ & $\begin{array}{c}4 \\
(21.1 \%) \\
\end{array}$ & $\begin{array}{c}6 \\
(31.6 \%) \\
\end{array}$ & $1(5.3 \%)$ & $1(5.3 \%)$ & $\begin{array}{c}2.21 \\
( \pm 1.18) \\
\end{array}$ & \\
\hline \multirow{2}{*}{$\begin{array}{l}\text { D1. I believe my teaching in } \\
\text { anatomy has been } \\
\text { appropriate for my clinical } \\
\text { needs in oral surgery }\end{array}$} & $\begin{array}{c}6^{\text {th }} \\
\text { year }\end{array}$ & $5(25 \%)$ & $\begin{array}{c}10 \\
(50 \%)\end{array}$ & $5(25 \%)$ & 0 & 0 & $\begin{array}{c}2.00 \\
( \pm 0.73)\end{array}$ & 0.696 \\
\hline & $\begin{array}{l}7^{\text {th }} \\
\text { year }\end{array}$ & $\begin{array}{c}7 \\
(36.8 \%) \\
\end{array}$ & $\begin{array}{c}9 \\
(47.4 \%) \\
\end{array}$ & $\begin{array}{c}1 \\
(5.3 \%)\end{array}$ & $\begin{array}{c}2 \\
(10.5 \%)\end{array}$ & 0 & $\begin{array}{c}1.89 \\
( \pm 0.94)\end{array}$ & \\
\hline \multirow{2}{*}{$\begin{array}{l}\text { D2. I am more confident } \\
\text { about undertaking oral } \\
\text { surgery because of my } \\
\text { knowledge and } \\
\text { understanding of head and } \\
\text { neck anatomy }\end{array}$} & $\begin{array}{c}6^{\text {th }} \\
\text { year }\end{array}$ & $1(5 \%)$ & $\begin{array}{c}10 \\
(50 \%)\end{array}$ & $7(35 \%)$ & $2(10 \%)$ & 0 & $\begin{array}{c}2.50 \\
( \pm 0.76)\end{array}$ & 0.777 \\
\hline & $\begin{array}{c}7^{\text {th }} \\
\text { year }\end{array}$ & $\begin{array}{c}2 \\
(10.5 \%) \\
\end{array}$ & $\begin{array}{c}10 \\
(52.6 \%) \\
\end{array}$ & $\begin{array}{c}5 \\
(26.3 \%) \\
\end{array}$ & $1(5.3 \%)$ & $1(5.3 \%)$ & $\begin{array}{c}2.42 \\
( \pm 0.96) \\
\end{array}$ & \\
\hline \multirow{2}{*}{$\begin{array}{l}\text { D3. The only anatomical } \\
\text { knowledge needed for oral } \\
\text { surgery is that of jaw and } \\
\text { tooth morphology }\end{array}$} & $\begin{array}{c}6^{\text {th }} \\
\text { year }\end{array}$ & 0 & $5(25 \%)$ & 0 & $5(25 \%)$ & $\begin{array}{c}10 \\
(50 \%)\end{array}$ & $\begin{array}{c}4.00 \\
( \pm 1.26)\end{array}$ & 0.887 \\
\hline & $\begin{array}{c}7^{\text {th }} \\
\text { year }\end{array}$ & $\begin{array}{c}1 \\
(5.3 \%) \\
\end{array}$ & $\begin{array}{c}1 \\
(5.3 \%) \\
\end{array}$ & 0 & $\begin{array}{c}11 \\
(57.9 \%) \\
\end{array}$ & $\begin{array}{c}6 \\
(31.6 \%) \\
\end{array}$ & $\begin{array}{c}4.05 \\
( \pm 1.03) \\
\end{array}$ & \\
\hline \multirow{2}{*}{$\begin{array}{l}\text { E1. Oral surgery is an } \\
\text { enjoyable and rewarding } \\
\text { discipline }\end{array}$} & $\begin{array}{c}6^{\text {th }} \\
\text { year }\end{array}$ & $8(40 \%)$ & $4(20 \%)$ & $3(15 \%)$ & $5(25 \%)$ & 0 & $\begin{array}{c}2.25 \\
( \pm 1.25)\end{array}$ & 0.477 \\
\hline & $\begin{array}{c}7^{\text {th }} \\
\text { year }\end{array}$ & $\begin{array}{c}4 \\
(21.1 \%)\end{array}$ & $\begin{array}{c}13 \\
(68.4 \%)\end{array}$ & $\begin{array}{c}1 \\
(5.3 \%)\end{array}$ & 0 & $1(5.3 \%)$ & $\begin{array}{c}2.00 \\
( \pm 0.88)\end{array}$ & \\
\hline
\end{tabular}


Table 3. Responses to questions regarding off-campus learning

\begin{tabular}{|c|c|c|c|c|c|c|}
\hline \multirow[t]{2}{*}{ Question } & \multicolumn{3}{|l|}{ Yes } & \multicolumn{3}{|l|}{ No } \\
\hline & $\begin{array}{l}6^{\text {th }} \\
\text { Year }\end{array}$ & $\begin{array}{l}7^{\text {th }} \\
\text { Year }\end{array}$ & All & $\begin{array}{l}6^{\text {th }} \\
\text { Year }\end{array}$ & $\begin{array}{l}7^{\text {th }} \\
\text { Year }\end{array}$ & All \\
\hline $\begin{array}{l}\text { C1. Where you involved in any rotation outside the } \\
\text { faculty of dentistry dental centre (off-campus) } \\
\text { scheme? }\end{array}$ & $\begin{array}{l}10 \\
(50 \%)\end{array}$ & $\begin{array}{l}13 \\
(68.4 \%)\end{array}$ & $\begin{array}{l}23 \\
(59.0 \%)\end{array}$ & $\begin{array}{l}10 \\
(50 \%)\end{array}$ & $\begin{array}{l}6 \\
(31.6 \%)\end{array}$ & $\begin{array}{l}16 \\
(41.0 \%)\end{array}$ \\
\hline $\begin{array}{l}\text { C2. Did you carry out any simple extractions outside } \\
\text { the faculty of dentistry dental centre (off-campus)? }\end{array}$ & $\begin{array}{l}7 \\
(35 \%)\end{array}$ & $\begin{array}{l}9 \\
(47.4 \%)\end{array}$ & $\begin{array}{l}16 \\
(41.0 \%)\end{array}$ & $\begin{array}{l}13 \\
(65 \%)\end{array}$ & $\begin{array}{l}10 \\
(52.6 \%)\end{array}$ & $\begin{array}{l}23 \\
(59.0 \%)\end{array}$ \\
\hline $\begin{array}{l}\text { C3. Did you carry out any surgical extractions } \\
\text { outside the faculty of dentistry dental centre (off- } \\
\text { campus)? }\end{array}$ & $\begin{array}{l}2 \\
(10 \%)\end{array}$ & 0 & \begin{tabular}{|l|}
2 \\
$(5.1 \%)$
\end{tabular} & $\begin{array}{l}18 \\
(90 \%)\end{array}$ & $\begin{array}{l}19 \\
(100 \%)\end{array}$ & $\begin{array}{l}37 \\
(94.9 \%)\end{array}$ \\
\hline
\end{tabular}

Table 4. Spearman's rho correlation coefficients ( $r$ ) for questions in section B (forceps and surgical extractions).

\begin{tabular}{|c|c|c|c|c|c|c|}
\hline Questions & B2 & B3 & B4a & B4b & B4c & B4d \\
\hline $\begin{array}{l}\text { B2. I feel confident that I could extract an upper } \\
\text { single rooted tooth with an intact crown, in an } \\
\text { otherwise intact dentition }\end{array}$ & 1.000 & - & - & - & - & - \\
\hline $\begin{array}{l}\text { B3. I feel confident that I could remove visible } \\
\text { retained roots of an upper left first molar with } \\
\text { elevators or forceps }\end{array}$ & $0.800^{* *}$ & 1.000 & - & - & - & - \\
\hline $\begin{array}{l}\text { B4a. I feel confident to assess and perform the } \\
\text { surgical management of a failed extraction (e.g. a } \\
\text { lower second molar) necessitating the raising of a } \\
\text { mucoperiosteal flap }\end{array}$ & $0.334^{*}$ & $0.322 *$ & 1.000 & - & - & - \\
\hline $\begin{array}{l}\text { B4b. I feel confident to assess and perform the } \\
\text { surgical management of a failed extraction (e.g. a } \\
\text { lower second molar) necessitating Bone removal }\end{array}$ & 0.288 & $0.326 *$ & $0.770 * *$ & 1.000 & - & - \\
\hline $\begin{array}{l}\text { B4c. I feel confident to assess and perform the } \\
\text { surgical management of a failed extraction (e.g. a } \\
\text { lower second molar) necessitating Sectioning the } \\
\text { tooth to facilitate elevation of the roots }\end{array}$ & $0.361 *$ & $0.428^{* *}$ & $0.786 * *$ & $0.788^{* *}$ & 1.000 & - \\
\hline $\begin{array}{l}\text { B4d. I feel confident to assess and perform the } \\
\text { surgical management of a failed extraction (e.g. a } \\
\text { lower second molar) necessitating Wound closure } \\
\text { using appropriate suture materials }\end{array}$ & $0.615^{* *}$ & $0.623 * *$ & $0.683 * *$ & $0.658 * *$ & $0.721^{* *}$ & 1.000 \\
\hline
\end{tabular}

$* * \mathrm{P}<0.01, * \mathrm{P}<0.05$ using a two-tailed test.

Table 5. Spearman's rho correlation coefficients ( $r$ ) for questions in section B (forceps and surgical exodontia) and section D (anatomy teaching) 


\begin{tabular}{|c|c|c|c|}
\hline Questions & $\begin{array}{l}\text { D1. I believe my } \\
\text { teaching in } \\
\text { anatomy has been } \\
\text { appropriate for my } \\
\text { clinical needs in } \\
\text { oral surgery } \\
\end{array}$ & $\begin{array}{l}\text { D2. I am more confident } \\
\text { about undertaking oral } \\
\text { surgery because of my } \\
\text { knowledge and } \\
\text { understanding of head } \\
\text { and neck anatomy } \\
\end{array}$ & $\begin{array}{l}\text { D3. The only } \\
\text { anatomical } \\
\text { knowledge needed } \\
\text { for oral surgery is } \\
\text { that of jaw and } \\
\text { tooth morphology }\end{array}$ \\
\hline $\begin{array}{l}\text { B1. The teaching that I have received } \\
\text { in oral surgery has given me sufficient } \\
\text { knowledge to undertake independent } \\
\text { practice }\end{array}$ & $0.372 *$ & 0.241 & 0.127 \\
\hline $\begin{array}{l}\text { B2. I feel confident that I could extract } \\
\text { an upper single rooted tooth with an } \\
\text { intact crown, in an otherwise intact } \\
\text { dentition }\end{array}$ & 0.258 & -0.136 & -0.209 \\
\hline $\begin{array}{l}\text { B3. I feel confident that I could remove } \\
\text { visible retained roots of an upper left } \\
\text { first molar with elevators or forceps }\end{array}$ & 0.168 & -0.185 & -0.019 \\
\hline $\begin{array}{l}\text { B4a. I feel confident to assess and } \\
\text { perform the surgical management of a } \\
\text { failed extraction (e.g. a lower second } \\
\text { molar) necessitating the raising of a } \\
\text { mucoperiosteal flap }\end{array}$ & $0.584^{* *}$ & $0.361 *$ & 0.005 \\
\hline $\begin{array}{l}\text { B4b. I feel confident to assess and } \\
\text { perform the surgical management of a } \\
\text { failed extraction (e.g. a lower second } \\
\text { molar) necessitating Bone removal }\end{array}$ & $0.468 * *$ & 0.199 & -0.293 \\
\hline $\begin{array}{l}\text { B4c. I feel confident to assess and } \\
\text { perform the surgical management of a } \\
\text { failed extraction (e.g. a lower second } \\
\text { molar) necessitating Sectioning the } \\
\text { tooth to facilitate elevation of the } \\
\text { roots }\end{array}$ & $0.484^{* *}$ & 0.130 & -0.135 \\
\hline $\begin{array}{l}\text { B4d. I feel confident to assess and } \\
\text { perform the surgical management of a } \\
\text { failed extraction (e.g. a lower second } \\
\text { molar) necessitating Wound closure } \\
\text { using appropriate suture materials }\end{array}$ & $0.320 *$ & -0.020 & -0.140 \\
\hline
\end{tabular}

$* * \mathrm{P}<0.01, * \mathrm{P}<0.05$ using a two-tailed test. 